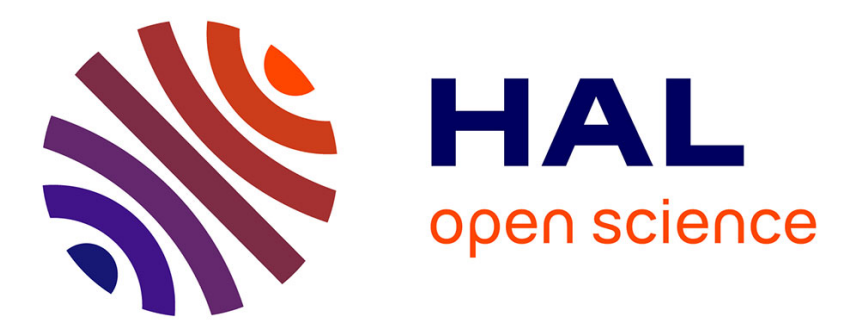

\title{
Dietary divercin modifies gastrointestinal microbiota and improves growth performance of broiler chickens
}

Damian Józefiak, Anna Sip, Mateusz Rawski, Andrzej Rutkowski, Sebastian Andrzej Kaczmarek, Ole Højberg, Bent Borg Jensen, Ricarda Margarete Engberg

\section{To cite this version:}

Damian Józefiak, Anna Sip, Mateusz Rawski, Andrzej Rutkowski, Sebastian Andrzej Kaczmarek, et al.. Dietary divercin modifies gastrointestinal microbiota and improves growth performance of broiler chickens. British Poultry Science, 2011, 52 (04), pp.492-499. 10.1080/00071668.2011.602963 . hal00732530

\section{HAL Id: hal-00732530 \\ https://hal.science/hal-00732530}

Submitted on 15 Sep 2012

HAL is a multi-disciplinary open access archive for the deposit and dissemination of scientific research documents, whether they are published or not. The documents may come from teaching and research institutions in France or abroad, or from public or private research centers.
L'archive ouverte pluridisciplinaire $\mathbf{H A L}$, est destinée au dépôt et à la diffusion de documents scientifiques de niveau recherche, publiés ou non, émanant des établissements d'enseignement et de recherche français ou étrangers, des laboratoires publics ou privés. 


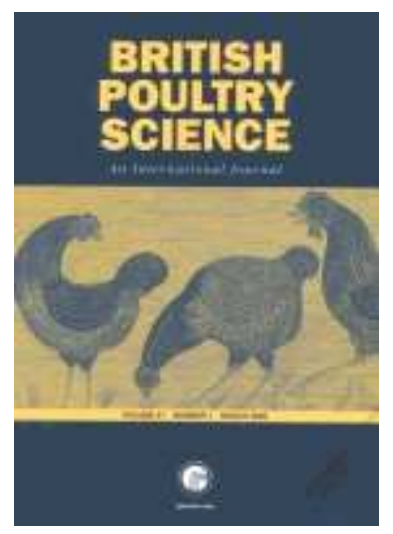

\section{Dietary divercin modifies gastrointestinal microbiota and improves growth performance of broiler chickens}

\begin{tabular}{|r|l|}
\hline Journal: & British Poultry Science \\
\hline Manuscript ID: & CBPS-2010-359.R1 \\
\hline Manuscript Type: & Original Manuscript \\
\hline Author: & 02-Mar-2011 \\
\hline Complete List of Authors: & $\begin{array}{l}\text { Józefiak, Damian; University of Life Sciences in Poznan, } \\
\text { Department of Animal Nutrition and Feed Management } \\
\text { Sip, Anna; University of Life Sciences in Poznan, Department of } \\
\text { Biotechnology and Food Microbiology } \\
\text { Rawski, Mateusz; University of Life Sciences in Poznan, Department } \\
\text { of Animal Nutrition and Feed Management } \\
\text { Rutkowski, Andrzej; University of Life Sciences in Poznan, } \\
\text { Department of Animal Nutrition and Feed Management } \\
\text { Kaczmarek, Sebastian; University of Life Sciences in Poznan, } \\
\text { Department of Animal Nutrition and Feed Management } \\
\text { Højberg, Ole; University of Aarhus, Faculty of Agricultural Sciences, } \\
\text { Dept. of Animal Health, Welfare and Nutrition } \\
\text { Jensen, Bent; University of Aarhus, Faculty of Agricultural Sciences, } \\
\text { Dept. of Animal Health, Welfare and Nutrition } \\
\text { Engberg, Ricarda; University of Aarhus, Faculty of Agricultural } \\
\text { Sciences, Dept. of Animal Health, Welfare and Nutrition }\end{array}$ \\
\hline Keywords: & \begin{tabular}{l} 
broiler chicken, bacteriocin, salinomycin, digestibility, microflora \\
\hline
\end{tabular} \\
\hline \hline
\end{tabular}

\section{SCHOLARONE Manuscripts}




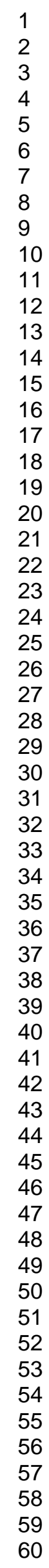

2

4

5

7

8

10

11

12

14

15

16

18

19

20

22

23

25

26

27

29

30

32

33

34

35

36

37

39

40

41

42

44

45

46

47

48

49

50

52

53

54

55

57

58

59

60

E-mail: br.poultsci@bbsrc.ac.uk URL: http://mc.manuscriptcentral.com/cbps 
2

3 Dietary divercin modifies gastrointestinal microbiota and improves growth

4 performance in broiler chickens

5

6 D. JOZEFIAK, A. SIP ${ }^{1}$, M. RAWSKI A. RUTKOWSKI, S. KACZMAREK, O.

$7 \quad$ HOJBERG $^{2}$, B. B., JENSEN ${ }^{2}$ AND R. M. ENGBERG ${ }^{2}$

8

9 Department of Animal Nutrition and Feed Management, University of Life Sciences in

10 Poznań, ul.Wotyńska 33, 60-637 Poznań, ' Department of Biotechnology and Food

11 Microbiology, ul. Wojska Polskiego 48, 60-627 Poznań, Poland and ${ }^{2}$ Aarhus

12 University, Faculty of Agricultural Sciences, Department of Animal Health and

13 Bioscience, PO Box 50, DK-8830 Tjele, Denmark

14

15

16

17

18

20

\section{Running title: Divercin in broiler chicken diets}


21 Abstract 1. The aim of the present study was to investigate the effects of dietary 22 administration of a divercin AS7 liquid preparation on broiler chicken performance, 23 nutrient digestibility, counts of lactic acid bacteria (LAB) and coliform bacteria, as 24 well as on the microbial activity in the gastrointestinal tract (GIT) as expressed by 25 digesta $\mathrm{pH}$ and concentrations of short-chain fatty acids and lactic acid.

26 2. A total of 450 1-d-old male Ross 308 chickens were randomly distributed to three 27 dietary treatments, with 15 pens per treatment and 10 birds per pen. The dietary 28 treatments consisted of a positive control (PC) supplemented with $60 \mathrm{mg} / \mathrm{kg}$ 29 salinomycin, a negative control (NC) without any additives, and the divercin (DIV) 30 supplemented diet containing $0.2 \mathrm{ml} / \mathrm{kg}$ of the liquid divercin AS7 preparation.

31 3. The dietary divercin AS7 supplementation significantly increased body weight gain 32 at $35 \mathrm{~d}$ compared to the $\mathrm{NC}$ group. Moreover, the $\mathrm{pH}$ of crop contents was higher and 33 that of caecal contents lower in birds fed on the divercin supplemented diets.

34 4. Significantly lower counts of LAB were observed in the crops and caeca of the birds 35 treated with divercin. Further, the divercin supplementation decreased lactic and 36 succinic acid concentrations in the crop and ileum.

37 5. The present study demonstrates that the use of divercin supplemented diets can 38 influence composition and activity of the microbiota in the broiler chicken GIT even in 39 the lower parts that should otherwise not be targeted due to the peptide structure of the 40 bacteriocin.

\section{INTRODUCTION}


42 In recent years, a number of studies have demonstrated a close relationship between 43 broiler performance, health and the gastrointestinal tract (GIT) microbiota (Engberg et 44 al., 2002; Maisonnier et al., 2003; Engberg et al., 2004; Choct 2009). Taking the 45 complexity and biodiversity of the GIT micro-ecosystem into consideration, a 46 manipulation of the GIT microbiota in a way that is profitable for the host-bird and for 47 the farmer, however, seems a difficult goal to achieve. Several studies have 48 demonstrated that the protective potential of the native commensal microbiota may 49 easily be disrupted by different nutritional factors (Dahiya et al. 2006; Choct 2009), 50 thereby compromising one of the suggested ways for the commensal microbiota to 51 support performance and health of broilers; namely elimination of pathogenic bacteria 52 from the GIT. On the other hand, it is also well recognised that the commensal 53 microbiota, no matter how protective it may be, does impose a burden upon the host

54 that goes beyond simply competing for feed components (Engberg et al., 2000), via 55 more specific mechanisms such as compromising fat digestibility (Knarreborg et al. 56 2002). A mere reduction in the commensal microbial load of the GIT may therefore, in 57 a short term perspective, represent a growth promoting factor for the host, though 58 admittedly, it may at the same time render the host more susceptible to pathogen 59 invasion.

60 Probiotics with potentially beneficial effects on broiler growth and health have 61 gained considerable interest (Choct 2009) and have been shown to stimulate the 62 immune system and to reduce the growth and intestinal colonisation of pathogenic 63 bacteria by competitive exclusion (Rijkers et al. 2010). Further, some probiotic 
64 bacteria produce different types of peptides, e.g. bacteriocins, with direct antimicrobial 65 effects (Joerger 2003). Even though bacteriocins have been used in human nutrition for 66 decades (Cleveland et al., 2001; Joerger 2003; Leisner et al., 2007), only limited 67 information is available regarding the effects of directly fed bacteriocins on broiler 68 chickens. A few recent publications do however indicate that different bacteriocins 69 administered with the feed may inhibit GIT colonisation by Campylobacter jejuni and 70 Salmonella enteritidis (Stern et al., 2005; Line et al., 2008). Among bacteria capable of producing bacteriocins, much attention has been 72 paid to the lactic acid bacteria, LAB (Stern et al., 2006; Svetoch et al., 2008). 73 Carnobacterium is a genus of LAB that can be isolated from various sources such as 74 the GIT of fish, dairy products and alpine permafrost (Leisner et al,. 2007). The 75 Carnobacterium genus comprises nine described species, of which Carnobacterium 76 divergens and Carnobacterium maltaromaticum have been most widely studied, due to 77 their role in the inhibition of many pathogenic and food spoilage bacteria such as 78 Clostridium, Bacillus, Brochothrix, Streptococcus, Staphylococcus and Micrococcus. 79 They do, however, also possess antimicrobial activity against fellow LAB of the genera 80 Lactobacillus, Leuconostoc, Carnobacterium, Pediococcus and Enterococcus (Sip et 81 al., 1998; Leisner et al., 2007); a feature potentially related to Carnobacterium 82 bacteriocin production.

83 Carnobacterium divergens produces the subclass IIa bacteriocins consisting of 8430 to 60 amino acids (Leisner et al. 2007) and so far, three major bacteriocins produced 85 by this species have been identified; divercin V41 (Rihakova et al. 2009), divercin AS7 
86 (Sip et al. 1998) and divergicin M35 (Tahiri et al. 2004). Apart from the data from our

87 preliminary study (Józefiak et al., 2010), no information is so far available on the use

88 of bacteriocins produced by Carnobacterium divergens as feed additives for broiler

89 chickens. The aim of the present study was therefore to investigate the effects of a

90 divercin AS7 preparation on broiler chicken performance, nutrient digestibility, counts

91 of coliform bacteria (indicator of potential pathogens) and LAB (representative

92 commensals) as well as on the microbial activity in the GIT expressed by the levels of $93 \mathrm{pH}$ and short-chain fatty acids.

\section{MATERIALS AND METHODS}

\section{$95 \quad$ Birds and housing}

96 The effect of the divercin AS7 supplementation was evaluated in a growth performance

97 experiment with broiler chickens kept in floor pens $(1.58 \times 1.16 \mathrm{~m})$ over an

98 experimental period of 35 d. A total of 450 1-d-old male ROSS 308 chicks were

99 randomly distributed to three dietary treatments using 15 replicate pens per treatment 100 and 10 birds per pen. The birds were given $23 \mathrm{~h}$ light and $1 \mathrm{~h}$ dark during the first 101 week, and then $19 \mathrm{~h}$ light and $5 \mathrm{~h}$ dark from $\mathrm{d} 7$ to 21 . From 22 to $42 \mathrm{~d}$ of age, there 102 was $23 \mathrm{~h}$ light and $1 \mathrm{~h}$ dark. The positive control (PC) diet was supplemented with an 103 ionophore coccidiostat (salinomycin, $60 \mathrm{mg} / \mathrm{kg}$ ), the negative control diet (NC) did not 104 contain any additive and the divercin diet (DIV) was supplemented with 200 AU 105 divercin $/ \mathrm{ml}(0.2 \mathrm{ml} / \mathrm{kg})$.

106 Diets and feeding programme

107 The compositions of the experimental diets are presented in Table 1. The divercin 
108 activity was quantified by two-fold dilutions, and expressed in activity units (AU) per

109 millilitre as previously described by Ennahar (2001). The divercin AS7 preparation

110 was produced according to the technology elaborated by Sip at al. (1999) and was

111 provided in liquid form. In the last $5 \mathrm{~d}$ of the experiment, $0.2 \%$ of the wheat was

112 replaced by titanium oxide as an internal marker for digestibility analyses. Table 1 near here

\section{Data collection}

114 The feed intake and body weight of the chickens were measured on $\mathrm{d} 14$ and 35 .

115 Mortality was registered throughout the entire experiment. At the end of the trial (35 d)

116 from each experimental group, 21 randomly picked chickens (three chickens from 7

117 pens) were killed by cervical dislocation. For analyses of gastrointestinal contents

118 (enumeration of bacteria, $\mathrm{pH}$ and organic acid concentrations), the contents of crop,

119 ileum and caecum from three birds per pen were pooled (7 replicate digesta samples of

120 approximately $10 \mathrm{~g})$. Approximately $5 \mathrm{~g}$ of the sample were used freshly for the

121 culturing of intestinal bacteria and for $\mathrm{pH}$ analyses. The rest of the samples were

122 immediately frozen and stored at $-20^{\circ} \mathrm{C}$ for the analysis of organic acids by gas

123 chromatography.

124 For the evaluation of apparent metabolisable energy $\left(\mathrm{AME}_{\mathrm{N}}\right)$ and nutrient

125 digestibility, a further 15 randomly chosen birds per treatment (one bird per pen) were

126 killed on d 35 and ileal contents were collected. The ileum was removed and digesta

127 were flushed from the terminal ileum $(15 \mathrm{~cm}$ adjacent to the ileo-caecal junction $)$. To

128 provide sufficient material for chemical analysis, the fresh ileal samples were pooled

129 into 5 replicates of approximately $60 \mathrm{~g}$. From the same pens excreta samples of approx. 
$130100 \mathrm{~g}$ were collected at $35 \mathrm{~d}$. The digesta and excreta samples were immediately

131 frozen, freeze-dried and ground before further analyses.

132 Chemical analyses

133 Feed samples were analysed in duplicate for crude protein, crude fat, and crude fibre 134 using AOAC (2005) methods 976.05, 920.39 and 2002.04, respectively. For all 135 chemical analysis, samples were ground to pass through a $0.5 \mathrm{~mm}$ sieve. Titanium 136 dioxide was determined according to the method described by Short et al. (1996), and 137 samples were prepared according to the procedure proposed by Myers et al. (2004). 138 Gross energy was determined using an adiabatic bomb calorimeter (KL 12Mn, 139 Precyzja-Bit PPHU, Poland) standardised with benzoic acid. Nitrogen content was 140 analysed by the Kjel Foss Automatic 16210 (A/S N. Foss Electric, Denmark) and the 141 crude protein content was calculated using a multiplication factor of 6.25. Fat content 142 was determined using Soxtex System HT 1043, Extraction Unit (Foss Tecator 143 Denmark).

\section{Microbiological analyses}

145 The $\mathrm{pH}$ of pooled digesta from the crop, ileum and caecum was measured immediately 146 after slaughter using a combined glass and reference electrode. The rest of the sample 147 (2.5 g), was diluted in $30 \mathrm{ml}$ of sterile pre-reduced salt medium (Miller and Wolin 148 1974). For enumeration of bacteria, the suspension was homogenised for two minutes 149 in $\mathrm{CO}_{2}$-flushed plastic bags using a stomacher homogeniser (Interscience, France). 150 Subsequently, the samples were serially diluted in 10-fold steps using pre-reduced salt 151 medium according to the technique of Miller and Wolin (1974). Lactic acid bacteria 
152 were enumerated by spread-plating on de Man, Rogosa and Sharp (MRS) agar (Merck 153 1.10660) incubated for $48 \mathrm{~h}$ at $38^{\circ} \mathrm{C}$ in anaerobic jars (Anaerocult ${ }^{\circledR} \mathrm{A}$, Merck 154 1.13829). Coliform bacteria were enumerated by spread-plating on MacConkey agar 155 (Merck 1.05465) incubated aerobically for $24 \mathrm{~h}$ at $38^{\circ} \mathrm{C}$.

156 The concentration of short-chain fatty acids and lactic acid in the contents of 157 the different gastrointestinal segments was determined by gas chromatography as 158 described earlier (Canibe et al., 2007) using a Hewlett Packard gas chromatograph 159 (Model 6890, Hewlett Packard, Agilent Technologies, Naerum, Denmark) equipped 160 with a flame-ionisation detector and a 30-m ZB-5 column with an internal diameter of $1610.32 \mathrm{~mm}$ and coated with 5\%-phenyl 95\%-dimethylpolysiloxane with a film thickness 162 of $0.25 \mu \mathrm{m}$. Total concentration of organic acids is expressed as the sum of acetic, 163 propionic, butyric, isobutyric, valeric, succinic and lactic acids.

\section{Digestibility calculations}

165 The following equations were used to calculate the apparent digestibility of the protein, 166 fat (using titanium dioxide and fat digestibility (dig.) calculation as an example) and $167 \quad \mathrm{AME}_{\mathrm{N}}$ content of experimental diets:

168

169 Fat dig. $(\%)=\left\{1-\left[\left(\mathrm{TiO}_{2} \%\right.\right.\right.$ diet $/ \mathrm{TiO}_{2} \%$ digesta/excreta $) \times($ fat $\%$ digesta/excretalfat $\%$ diet $\left.\left.)\right]\right\}$ $170 \times 100$

171

$172 A M E_{N}(\mathrm{~kJ} / \mathrm{kg})=G E_{\mathrm{kJ} / \mathrm{kg} \text { diet }}-\left[G E_{\mathrm{kJ} / \mathrm{kg} \text { excreta }} \cdot\left(\mathrm{TiO}_{2} \%_{\text {diet }} / \mathrm{TiO}_{2} \%_{\text {excreta }}\right)\right]-34.39 \cdot\left\{\mathrm{N} \%_{\text {diet }}\right.$ $\left.173-\left[\mathrm{N}_{\text {excreta }} \cdot\left(\mathrm{TiO}_{2} \%_{\text {diet }} / \mathrm{TiO}_{2} \%_{\text {excreta }}\right)\right\}\right]$ 
174

175 Where GE is gross energy, $\mathrm{N}$ is nitrogen, $\mathrm{TiO}_{2}$ is titanium oxide, and 34.39 is the

176 energy equivalent of uric acid nitrogen (i.e., $34.39 \mathrm{~kJ} / \mathrm{kg}$ uric acid nitrogen).

\section{Statistical analysis}

178 The study was set up as a completely randomised design, and data were tested using 179 the GLM procedure of SAS (SAS 1990). Means were separated using a Duncan's 180 multiple range test. All statements of significance are based on $P<0.05$.

\section{RESULTS}

182 Throughout the trial, the mortality was below $2 \%$ without any signs of viral or bacterial 183 infections. Birds fed on diets supplemented with salinomycin showed the best 184 performance results (Table 2). Compared with the non-supplemented control, the 185 divercin supplementation increased the body weight gain in the starter period $186(P=0.006)$ and at the end of the trial $(P<0.001)$, and tended to improve total feed 187 conversion ratio as well as feed intake in each growth stage. Tables 2 \& 3 near here

188 The levels of apparent metabolisable energy $\left(\mathrm{AME}_{\mathrm{N}}\right)$ and ileal digestible 189 energy (Table 3) increased after salinomycin supplementation $(P<0.001$ and $P=0.016$, 190 respectively). However, there was no difference between PC and DIV treatments with 191 respect to the estimated ileal digestible energy. Although the ileal crude fat digestibility 192 of birds fed the PC diet was approximately 24 percentage points higher than that of the 193 other groups (0.92 vs. 0.68), no statistical significant difference was found $(P=0.118)$. 194 Total tract fat digestibility was significantly higher $(P=0.013)$ in the PC group (Table 
195 3). The lowest ileal crude protein digestibility, as well as total nitrogen retention, was

196 observed in the birds fed the NC diet.

Table 4 near here

In the present trial, the dietary supplementation with salinomycin numerically

198 increased the counts of LAB bacteria (Table 4), but only significantly in the caecum

$199(P=0.015)$. Divercin tended to reduce the LAB population in the contents of the crop

$200(P=0.14)$. However in the ileum $(P=0.015)$ and caecum $(P=0.006)$ the reduction was

201 significant. The counts of coliform bacteria in the different intestinal segments were

202 not influenced by the dietary treatments $(P>0.05)$.

203 Compared with the non-supplemented controls, the digesta $\mathrm{pH}$ in crop and

204 ileum was higher when birds were fed salinomycin and divercin $(P=0.011$ and $205 P=0.001$, respectively). In the caecum, the $\mathrm{pH}$ was highest in the non-supplemented 206 control $(P=0.043)$.

Table 5 near here

207 In crop contents, the dominant organic acids were lactic acid and acetic acid 208 (Table 5), while succinic acid and butyric acid were detected in small concentrations. 209 Compared with the non-supplemented diet, the addition of salinomycin and divercin 210 reduced lactic acid, acetic acid and succinic acid concentrations by approximately $50 \%$ $211(P>0.001)$ in crop contents. Also in ileal content, the most abundant organic acids were 212 lactic and acetic acid, whereas succinic acid was detected only in low concentrations 213 (Table 5). The concentration of lactic acid was influenced by the dietary treatment $214(P<0.001)$ and was lowest in ileal contents of birds supplemented with salinomycin $215(34.5 \mu \mathrm{g} / \mathrm{g})$, as compared with divercin $(72.4 \mu \mathrm{g} / \mathrm{g})$ and the non-supplemented control 216 diet $(114.0 \mu \mathrm{g} / \mathrm{g})$. The concentration of acetic acid in ileal contents was not influenced 
217 by the dietary treatment $(P>0.05)$. In caecal contents, the organic acid profile was 218 much more diverse with acetic acid, butyric acid and propionic acid being the 219 dominant organic acids (Table 5). Low concentrations of isobutyric, isovaleric and 220 valeric acids were detected in caecal contents, whereas lactic acid was not detected at 221 this location. In general, divercin reduced the microbial fermentation to the same extent 222 as salinomycin (Table 5). There was no difference between groups with respect to the 223 production of organic acids in the caecum $(P>0.05)$.

224

\section{DISCUSSION}

225 The observed growth promoting effect of salinomycin is in good agreement with 226 earlier studies on broiler chickens (Engberg et al., 2000), ruminants (Spears 1990) and 227 pigs (Moore et al., 1986). In poultry, many of the applied ionophore coccidiostats do 228 not only target Eimeria species but also certain Gram-positive GIT bacteria. These 229 substances have been observed to reduce the numbers of, for example, Clostridium 230 perfringens (Bjerrum et al., 2005) and LAB, including species like Lactobacillus 231 salivarius, previously reported to be dominating in the broiler GIT (Engberg et al., 232 2000). The improvement of bird growth and feed utilisation imposed by salinomycin 233 may be explained by a limitation of microbial growth and activity per se, alleviating 234 the direct competition with the host for nutrients. More specifically, by targeting 235 bacteria responsible for deconjugation of bile salts (Knarreborg et al. 2002; Guban et 236 al. 2006), salinomycin treatment may also improve fat digestibility (Knarreborg et al. 237 2004). In accordance with this, the present study demonstrated an increased fat 238 digestibility and $\mathrm{AME}_{\mathrm{N}}$ content after dietary salinomycin supplementation. The $\mathrm{AME}_{\mathrm{N}}$ 
239 content was actually higher than the calculated energy value of the diets (13.6 vs. 13.0

$240 \mathrm{MJ} / \mathrm{kg}$ ). Compared with the NC diet, the ileal digestible energy increased after 241 divercin supplementation (10.3 vs. $11.6 \mathrm{MJ} / \mathrm{kg}$ ), being in between the $\mathrm{NC}$ and the PC 242 diet. Both additives also improved ileal crude protein digestibility as well as nitrogen 243 retention. The present results thus suggest that the divercin-medicated improvement in 244 broiler growth performance $(P=0.001)$ and feed utilisation $(P=0.059)$ may be directly 245 linked to an improved nutrient digestibility, due to a reduction of the GIT microbial 246 load and activity..

247 Dietary supplementation with different bacteriocins has been shown to suppress 248 different pathogenic bacteria. Cole et al. (2006) demonstrated significant reduction of 249 Campylobacter jejuni in turkey poults after dietary addition of bacteriocin B602 from 250 Paenibacillus polymyxa (NRRL B-30509), and bacteriocin OR7 from Lactobacillus 251 salivarius (NRRL B-35014). Enterococcus faecium strain J96 isolated from the crop of 252 a chicken showed protective effects on chickens infected with Salmonella pullorum 253 (Audisio et al., 1999). Mountzouris et al. (2010) examined avilamicin and a probiotic 254 product based on 5 bacterial species isolated from the crop (Lactobacillus reuteri DSM 255 16350), jejunum (Enterococcus faecium DSM 16211), ileum (Bifidobacterium 256 animalis DSM 16284), and caecum (Pediococcus acidilactici DSM 16210, and 257 Lactobacillus salivarius DSM 16351) of healthy adult chickens. These bacteria are all 258 capable of producing bacteriocins (Cleveland et al., 2001; Joerger 2003; Diez259 Gonzalez, 2007; Nazef et al., 2008), and it has thus been concluded that some of the 260 growth promoting effects were linked to antimicrobial activity of those peptides. 
261 However, the highest ileal apparent digestibility coefficients of crude protein and ether 262 extract were observed in avilamycin supplemented treatment, followed by the 263 probiotic-supplemented group (Mountzouris et al., 2010).

264 Grilli et al., (2009) showed that pediocin A from Pediococcus pentosaceus 265 FBB61, belonging to the class III bacteriocins, significantly improved growth 266 performance of broiler chickens challenged with Clostridium perfringens. In the 267 present study, we did not enumerate specific pathogens. However, the experimental 268 diets provided animal fat sources (lard and tallow) known to stimulate the intestinal 269 growth of Clostridium perfringens (Knarreborg et al., 2004). It cannot be excluded 270 therefore, that some of the observed salinomycin and divercin effects may be linked to 271 a suppression of $C$. perfringens; a very active player in bile acid de-conjugation 272 (Knarreborg et al., 2002).

273 Lactobacilli are among the most abundant bacteria in the chicken GIT and 274 typically dominate in the upper GIT segments (crop, gizzard and ileum). Lu et al. 275 (2003) thus reported approx. $70 \%$ of the sequences in an ileum-derived 16S rRNA 276 gene library to be allocated to the Lactobacillus genus. In the caecum, on the other 277 hand, where strict anaerobes proliferate readily, lactobacilli only accounted for approx. $2788 \%$ of the library sequences ( $\mathrm{Lu}$ et al., 2003). Lactic acid bacteria are usually 279 considered beneficial for the host bird due to their production of, for example, lactic 280 and acetic acids, leading to $\mathrm{pH}$ reduction (Engberg et al., 2004), as well as their 281 production of certain bacteriocins (Nazef et al., 2008). On the other hand, there is also 282 certain evidence that some small intestine LAB, e.g. Lactobacillus salivarius and 
283 Enterococcus faecium might have negative effects on broiler performance (Engberg et 284 al. 2000; Guban et al. 2006).

285 In general, the observations of the present study suggest salinomycin as well as 286 divercin can suppress the overall microbial activity of the broiler GIT; the 287 concentration of organic acids was thus highest in the non-supplemented control group 288 in each GIT segment (Table 5), though not significant for the caecum, and the observed 289 levels of total and individual organic acids were in good agreement with our earlier 290 studies (Józefiak et al., 2006; Józefiak et al., 2007). The suppression of the microbial 291 activity by salinomycin and divercin is clearly reflected in the pH levels of the upper 292 GIT segments, but not in the caecum; an apparent discrepancy also observed earlier 293 (Engberg et al., 2000). More specifically, the LAB activity also seemed to be 294 suppressed by salinomycin and divercin, as indicated by the lower lactic acid 295 concentrations and higher $\mathrm{pH}$ in the upper parts of the GIT (crop and ileum), compared 296 with the control group. Surprisingly, however, significant reduction of the LAB (MRS) 297 counts was only observed in the ileum of the divercin treated broilers, whereas 298 salinomycin actually increased caecal LAB counts; a discrepancy that cannot be readily 299 explained, but similar trends have been observed before (Engberg et al., 2000) and it 300 emphasises the complexity of the mechanisms involved. In particular, the question of 301 which species of broiler GIT lactic acid bacteria may be targeted by divercin and 302 salinomycin remains unanswered, as no detailed identification of the involved LAB has 303 been conducted.

304 A recent study by Shin et al. (2008) showed that the broiler chicken GIT is inhabited 
305 by many bacteriocin-producing bacteria with antibacterial activity against pathogens.

306 Even though carnobacteria are relatively widespread in nature, however, there is so far

307 no evidence that they are present in the GIT of broiler chickens (Leisner et al., 2007); a

308 fact that may explain the strong effects of divercin AS7 introduction on bacterial 309 fermentative activity. The fact that divercin AS7 in the present study tended to 310 suppress LAB even in the caecum indicates that this bacteriocin, even in an 311 unprotected form, may continue to be active in the lower segments of the broiler GIT, 312 although, as a protein, it is prone to hydrolysis in the upper intestine.

313 To our knowledge, the present study is the first attempt to use a

314 Carnobacterium divergens bacteriocin as a feed supplement and to demonstrate 315 positive growth promoting and antibacterial effects of divercin in broiler chickens. 316 Although consistent with our preliminary studies (Józefiak et al. 2010), the results 317 presented here should be followed up by further investigations in order to provide 318 more detailed information on broiler growth performance, for example, in response to 319 different divercin doses; as well as the specific bacteria being targeted by the 320 bacteriocin. Finally, it could be attempted to increase the effectiveness of divercin in 321 the broiler GIT by protective encapsulation of the peptide.

\section{REFERENCES}

323 AOAC (2005) Official Methods of of Official Analytical Chemists. 18th ed. AOAC 324 International, Arlington, VA.

325 Audisio, M. C., Oliver, G. \& Apella, M. C. (1999) Antagonistic effect of 326 Enterococcus faecium J96 against human and poultry pathogenic Salmonella spp. 327 Journal of Food Protection, 62: 751-755. 
328 Bjerrum, L., Pedersen, A. B. \& Engberg, R. M. (2005) The influence of whole 329 wheat feeding on Salmonella infection and gut flora composition in broilers. Avian 330 Diseases, 49: 9-15.

331 Canibe, N., Hojberg, O., Badsberg, J. H. \& Jensen, B. B. (2007) Effect of feeding 332 fermented liquid feed and fermented grain on gastrointestinal ecology and growth 333 performance in piglets. Journal of Animal Science, 85: 2959-2971.

334 Сност, M. (2009) Managing gut health through nutrition. British Poultry Science, 50: $3359-15$.

336 Cleveland, J., Montville, T. J., Nes, I. F. \& Chikindas, M. L. (2001) Bacteriocins: 337 safe, natural antimicrobials for food preservation. International Journal of Food 338 Microbiology, 71: 1-20.

339 Cole, K., Farnell, M., Donoghue, A., Stern, N., Svetoch, E., Eruslanov, B., 340 Volodina, L., Kovalev, Y., Perelygin, V. \& Mitsevich, E. (2006) Bacteriocins 341 reduce Campylobacter colonization and alter gut morphology in turkey poults. Poultry 342 Science, 85: 1570.

343 Dahiya, J., Wilkie, D., Van Kessel, A. \& Drew, M. (2006) Potential strategies for 344 controlling necrotic enteritis in broiler chickens in post-antibiotic era. Animal Feed 345 Science and Technology, 129: 60-88.

346 DieZ-GonZalez, F. (2007) Applications of bacteriocins in livestock. Current Issues 347 in Intestinal Microbiology, 8: 15.

348 Engberg, R. M., Hedemann, M. S., Leser, T. D. \& Jensen, B. B. (2000) Effect of 349 zinc bacitracin and salinomycin on intestinal microflora and performance of broilers. 350 Poultry Science, 79: 1311.

351 Engberg, R. M., Hedemann, M. S. \& Jensen, B. B. (2002) The influence of grinding 352 and pelleting of feed on the microbial composition and activity in the digestive tract of 353 broiler chickens. British Poultry Science, 43: 569-579.

354 Engberg, R., Hedemann, M., Steenfeldt, S. \& Jensen, B. (2004) Influence of 355 whole wheat and xylanase on broiler performance and microbial composition and 356 activity in the digestive tract. Poultry Science, 83: 925. 
357 Ennahar, S., Asou, Y., Zendo, T., Sonomoto, K. \& Ishizaki, A. (2001)

358 Biochemical and genetic evidence for production of enterocins $A$ and $B$ by 359 Enterococcus faecium WHE 81. International Journal of Food Microbiology, 70: 291360301.

361 Grilli, E., Messina, M. R., Catelli, E., Morlacchini, M. \& Piva, A. (2009) 362 Pediocin A improves growth performance of broilers challenged with Clostridium 363 perfringens. Poultry Science, 88: 2152-2158.

364 Guban, J., Korver, D. R., Allison, G. E. \& Tannock, G. W. (2006) Relationship of 365 Dietary Antimicrobial Drug Administration with Broiler Performance, Decreased 366 Population Levels of Lactobacillus salivarius, and Reduced Bile Salt Deconjugation in 367 the Ileum of Broiler Chickens. Poultry Science, 85: 2186-2194.

368 JOERGER, R. (2003) Alternatives to antibiotics: bacteriocins, antimicrobial peptides 369 and bacteriophages. Poultry Science, 82: 640.

370 Józefiak, D., Rutkowski, A., Jensen, B. B. \& Engberg, R. M. (2006) The effect of $371 \beta$-glucanase supplementation of barley- and oat-based diets on growth performance and 372 fermentation in broiler chicken gastrointestinal tract. British Poultry Science, 47: 57 37364.

374 Józefiak, D., Rutkowski, A., Jensen, B. B. \& Engberg, R. M. (2007) Effects of 375 dietary inclusion of triticale, rye and wheat and xylanase supplementation on growth 376 performance of broiler chickens and fermentation in the gastrointestinal tract. Animal 377 Feed Science and Technology, 132: 79-93.

378 Józefiak, D., Sip, A., Kaczmarek, S. \& RutKowski, A. (2010) The effects of 379 Carnobacterium divergens AS7 bacteriocin on gastrointestinal microflora in vitro and 380 on nutrient retention in broiler chickens. Journal of Animal and Feed Sciences, 19: $381460-467$.

382 Knarreborg, A., Engberg, R. M., Jensen, S. K. \& Jensen, B. B. (2002) 383 Quantitative determination of bile salt hydrolase activity in bacteria isolated from the 384 small intestine of chickens. Applied and Environmental Microbiology, 68: 6425-6428. 
385 386 387 388 389 390 391 392 393 394 395 402 403 404 405 406 407 408 409 410 411
Knarreborg, A., Lauridsen, C., Engberg, R. M. \& Jensen, S. K. (2004) Dietary antibiotic growth promoters enhance the bioavailability of alpha-tocopheryl acetate in broilers by altering lipid absorption. Journal of Nutrition, 134: 1487-1492.

Leisner, J. R. J., Laursen, B. G., PrÈvost, H., Drider, D. \& DalgaArd, P. (2007) Carnobacterium: positive and negative effects in the environment and in foods. FEMS Microbiology Reviews, 31: 592-613.

Line, J. E., Svetoch, E. A., Eruslanov, B. V., Perelygin, V. V., Mitsevich, E. V., Mitsevich, I. P., Levchuk, V. P., Svetoch, O. E., Seal, B. S., Siragusa, G. R. \& STERN, N. J. (2008) Isolation and purification of enterocin E-760 with broad antimicrobial activity against gram-positive and gram-negative bacteria. Antimicrobial Agents and Chemotherapy, 52: 1094-1100.

Lu, J., Idris, U., Harmon, B., Hofacre, C., Maurer, J. J. \& Lee, M. D. (2003) Diversity and succession of the intestinal bacterial community of the maturing broiler chicken. Applied and Environmental Microbiology, 69: 6816-6824.

Maisonnier, S., Gomez, J., Bree, A., Berri, C., Baeza, E. \& Carre, B. (2003) Effects of microflora status, dietary bile salts and guar gum on lipid digestibility, intestinal bile salts, and histomorphology in broiler chickens. Poultry Science, 82: 805814.

Miller, T. L. \& Wolin, M. J. (1974) A serum bottle modification of the Hungate technique for cultivating obligate anaerobes. Applied Microbiology, 27: 985-987.

Moore, R. J., Kornegay, E. T. \& D., L. M. (1986) Effect of salinomycin on nutrient absorption and retention by growing pigs fed corn-soybean meal diets with or without oat hulls or wheat bran. Canadian Journal of Animal Science, 66: 257-265.

Mountzouris, K. C., Tsitrsikos, P., Palamidi, I., Arvaniti, A., Mohnl, M., Schatzmayr, G. \& Fegeros, K. (2010) Effects of probiotic inclusion levels in broiler nutrition on growth performance, nutrient digestibility, plasma immunoglobulins, and cecal microflora composition. Poultry Science, 89: 58-67.

E-mail: br.poultsci@bbsrc.ac.uk URL: http://mc.manuscriptcentral.com/cbps 
412 Myers, W. D., Ludden, P. A., Nayigihugu, V. \& Hess, B. W. (2004) Technical

413 Note: A procedure for the preparation and quantitative analysis of samples for titanium 414 dioxide. Journal of Animal Science, 82: 179-183.

415 Nazef, L., Belguesmia, Y., Tani, A., Prevost, H. \& Drider, D. (2008) 416 Identification of lactic acid bacteria from poultry feces: evidence on anti417 Campylobacter and anti-Listeria activities. Poultry Science, 87: 329.

418 Rihakova, J., Petit, V. W., Demnerova, K., Prevost, H., Rebuffat, S. \& Drider, 419 D. (2009) Insights into Structure-Activity Relationships in the C-Terminal Region of 420 Divercin V41, a Class IIa Bacteriocin with High-Level Antilisterial Activity. Applied 421 and Environmental Microbiology, 75: 1811-1819.

422 Rijkers, G. T., Bengmark, S., Enck, P., Haller, D., Herz, U., Kalliomaki, M., 423 Kudo, S., Lenoir-Wijnkoop, I., Mercenier, A., Myllyluoma, E., Rabot, S., 424 Rafter, J., Szajewska, H., Watzl, B., Wells, J., Wolvers, D. \& Antoine, J.-M. 425 (2010) Guidance for Substantiating the Evidence for Beneficial Effects of Probiotics: 426 Current Status and Recommendations for Future Research. Journal of Nutrition, 140: 427 671S-676.

428 SAS (1990) SAS User's Guide: Statistics. Version 6. 4th ed SAS Institute, Cary, NC.

429 ShIn, M. S., HAn, S. K., Ji, A. R., KIM, K. S. \& LEE, W. K. (2008) Isolation and 430 characterization of bacteriocin-producing bacteria from the gastrointestinal tract of 431 broiler chickens for probiotic use. Journal, 105: 2203-2212.

432 Short, F. J., Gorton, P., Wiseman, J. \& Boorman, K. N. (1996) Determination of 433 titanium dioxide added as an inert marker in chicken digestibility studies. Animal Feed $434 \quad$ Science and Technology, 59: 215-221.

435 SiP, A., GrajeK, W. \& Boyaval, P. (1998) Enhancement of bacteriocin production 436 by Carnobacterium divergens AS7 in the presence of a bacteriocin-sensitive strain 437 Carnobacterium piscicola. International Journal of Food Microbiology, 42: 63-69.

438 SiP, A., GrajeK, W. \& Boyaval, P. (1999) Production of bacteriocin by 439 Carnobacterium divergens in batch and continuous culture. Polish Journal of Food and $440 \quad$ Nutrition Sciences 8/49: 27-38. 
441 Spears, J. W. (1990) Ionophores and Nutrient Digestion and Absorption in 442 Ruminants. Journal of Nutrition, 120: 632-638.

443 Stern, N. J., Svetoch, E. A., Eruslanov, B. V., Kovalev, Y. N., Volodina, L. I., 444 Perelygin, V. V., Mitsevich, E. V., Mitsevich, I. P. \& Levchuk, V. P. (2005) 445 Paenibacillus polymyxa purified bacteriocin to control Campylobacter jejuni in 446 chickens. Journal of Food Protection, 68: 1450-1453.

447 Stern, N. J., Svetoch, E. A., Eruslanov, B. V., Perelygin, V. V., Mitsevich, E. V., 448 Mitsevich, I. P., Pokhilenko, V. D., Levchuk, V. P., Svetoch, O. E. \& Seal, B. S. 449 (2006) Isolation of a Lactobacillus salivarius strain and purification of its bacteriocin, 450 which is inhibitory to Campylobacter jejuni in the chicken gastrointestinal system. 451 Antimicrobial Agents and Chemotherapy, 50: 3111-3116.

452 Svetoch, E. A., Levchuk, V. P., Pokhilenko, V. D., Eruslanov, B. V., Mitsevich, 453 E. V., Mitsevich, I. P., Perelygin, V. V., Stepanshin, Y. G. \& Stern, N. J. (2008) 454 Inactivating methicillin-resistant Staphylococcus aureus and other pathogens by use of 455 bacteriocins OR-7 and E 50-52. Journal of Clinical Microbiology, 46: 3863-3865.

456 Tahiri, I., Desbiens, M., Benech, R., Kheadr, E., Lacroix, C., Thibault, S., 457 Ouellet, D. \& Fliss, I. (2004) Purification, characterization and amino acid 458 sequencing of divergicin M35: a novel class IIa bacteriocin produced by 459 Carnobacterium divergens M35. International Journal of Food Microbiology, 97: 123460136.

461

462

463

464

465

466

E-mail: br.poultsci@bbsrc.ac.uk URL: http://mc.manuscriptcentral.com/cbps 
469 Table 1. Composition of the basal diets and their calculated nutritive value

Wheat

Barley

Soyabean meal

Beef tallow

$30 \cdot 0$

Pig lard

$53 \cdot 7$

Double zero rapeseed meal

$60 \cdot 0$

Fish meal

$30 \cdot 0$

$11 \cdot 0$

Mineral-vitamin premix

Limestone

L-Lysine - $\mathrm{HCl}$

$4 \cdot 2$

$2 \cdot 8$

$2 \cdot 1$

$0 \cdot 3$

$1 \cdot 0$

$2 \cdot 6$

$2 \cdot 0$

um oxide $\left(\mathrm{TiO}_{2}\right)$

Calculated nutritive value $\left(\mathrm{g}^{-1}\right.$

$\mathrm{ME}\left(\mathrm{MJ} \mathrm{kg}^{-1}\right)$

$12 \cdot 95$

Crude protein

$220 \cdot 0$

Crude fat

$100 \cdot 0$

Crude fibre \%

$34 \cdot 50$

Calcium - Ca \%

$8 \cdot 50$

Lysine \%

$13 \cdot 0$

Methionine \%

$5 \cdot 5$

Methionine + Cystine \%

$9 \cdot 3$

$8 \cdot 1$

$\mathrm{P}$ avilaible.

\section{Analysed composition $\left(g \mathrm{~kg}^{-1}\right)$}

Crude protein

$214 \cdot 0$

Crude fibre

$39 \cdot 2$

Crude fat

$101 \cdot 2$

$\mathrm{ME}\left(\mathrm{MJ} \mathrm{kg}^{-1}\right)$

470 a Providing the following per kilogram of diet: vitamin A (retinol), $11.166 \mathrm{IU}$; cholecalciferol, 2.500 IU; 471 vitamin E (alpha tocopherol), $80 \mathrm{mg}$; menadione, $2.50 \mathrm{mg}$; cobalamin, $0.02 \mathrm{mg}$; folic acid, $1.17 \mathrm{mg}$; choline, $379 \mathrm{mg}$; D-pantothenic acid, $12.50 \mathrm{mg}$; riboflavin, $7.0 \mathrm{mg}$; niacin, $41.67 \mathrm{mg}$; thiamin, $2.17 \mathrm{mg}$; D-biotin, $0.18 \mathrm{mg}$; pyridoxine, $4.0 \mathrm{mg}$; ethoxyquin, $0.09 \mathrm{mg}$; $\mathrm{Mn}\left(\mathrm{MnO}_{2}\right), 73 \mathrm{mg}$; $\mathrm{Zn}(\mathrm{ZnO}), 55 \mathrm{mg}$; $\mathrm{Fe}$ $\left(\mathrm{FeSO}_{4}\right), 45 \mathrm{mg} ; \mathrm{Cu}\left(\mathrm{CuSO}_{4}\right), 20 \mathrm{mg} ; \mathrm{I}\left(\mathrm{CaI}_{2} \mathrm{O}_{6}\right), 0.62 \mathrm{mg} ; \mathrm{Se}\left(\mathrm{Na}_{2} \mathrm{SeO}_{3}\right), 0.3 \mathrm{mg}$.

${ }^{\mathrm{b}}$ Replaced corresponding amount of the wheat in each diet, from 30-35 $\mathrm{d}$ of broiler growth 
Table 2. Performance results

\begin{tabular}{|c|c|c|c|c|c|}
\hline \multirow{3}{*}{ Item } & \multicolumn{3}{|c|}{ Treatment } & \multirow[b]{2}{*}{$\mathrm{SEM}^{\mathrm{d}}$} & \multirow[b]{2}{*}{$P^{\mathrm{e}}$} \\
\hline & $\mathrm{PC}^{\mathrm{a}}$ & $\mathrm{NC}^{\mathrm{b}}$ & $\mathrm{DIV}^{\mathrm{c}}$ & & \\
\hline & \multicolumn{3}{|c|}{ Feed conversion ratio ( $\mathrm{g}$ feed/g gain } & & \\
\hline $1-14 d$ & $1.48^{\mathrm{y}}$ & $1.54^{\mathrm{x}}$ & $1.49^{\mathrm{y}}$ & 0.01 & 0.001 \\
\hline $14-35 d$ & 1.60 & 1.67 & 1.67 & 0.02 & 0.140 \\
\hline \multirow{2}{*}{$1-35 d$} & 1.58 & 1.65 & 1.61 & 0.01 & 0.059 \\
\hline & \multicolumn{3}{|c|}{ Body weight gain (g/bird) } & & \\
\hline $1-14 d$ & $328^{x}$ & $304^{y}$ & $320^{x}$ & 3.37 & 0.006 \\
\hline $14-35 d$ & $1474^{\mathrm{x}}$ & $1360^{\mathrm{y}}$ & $1413^{x y}$ & 14.25 & 0.003 \\
\hline \multirow[t]{2}{*}{$1-35 d$} & $1801^{\mathrm{x}}$ & $1664^{\mathrm{z}}$ & $1733^{\mathrm{y}}$ & 15.83 & $<0.001$ \\
\hline & \multicolumn{3}{|c|}{ Feed intake (g/bird) } & & \\
\hline $1-14 d$ & 484 & 469 & 476 & 3.77 & 0.236 \\
\hline $14-35 d$ & 2357 & 2274 & 2349 & 18.99 & 0.138 \\
\hline $1-35 d$ & 2838 & 2737 & 2790 & 18.21 & 0.074 \\
\hline
\end{tabular}

${ }^{\mathrm{a}}$ The positive control (PC) diet contained $60 \mathrm{mg} / \mathrm{kg}$ of salinomycin

$479{ }^{\mathrm{b}}$ The negative control (NC) diet did not contain any additives

$480{ }^{\mathrm{c}}$ The divercin supplemented diet contained $200 \mathrm{AU}$ of divercin $/ \mathrm{ml}(0.2 \mathrm{ml} / \mathrm{kg})$

$481{ }^{\mathrm{d}}$ SEM - standard error of the mean

$482{ }^{\mathrm{e}} P$ - probability

$483 \mathrm{x}, \mathrm{y}, \mathrm{z}$ Within rows, mean values without a common superscript differ significantly.

484

485

486

487 
Table 3. Ileal digestibility of nutrients and energy, nitrogen retention and $A M E_{N}$

491 content.

Item

Ileal digestible energy Treatment

Ileal crude protein digestibility

N Retention

Ileal crude fat digestibility $\mathrm{NC}^{\mathrm{b}}$

\begin{tabular}{cc}
\hline $\mathrm{PC}^{\mathrm{a}}$ & $\mathrm{NC}^{\mathrm{b}}$ \\
\hline $13.6^{\mathrm{x}}$ & $(\mathrm{kcal})$ \\
$12.1^{\mathrm{y}}$
\end{tabular}

$12.1^{\mathrm{y}}$

$\begin{array}{ll}12.9^{\mathrm{x}} & 10.3^{\mathrm{y}}\end{array}$

$11.6^{\mathrm{xy}}$

0.440

$<0.001$

Total tract fat digestibility

0.74

0.74
$0.49^{\mathrm{x}}$

0.62

0.70

0.021

0.074

0.92

$0.37^{\mathrm{y}}$

$0.40^{\text {xy }}$

0.021

0.048

$0.90^{\mathrm{x}}$

$0.76^{\mathrm{y}}$

$0.72^{\mathrm{x}}$

0.055

0.118

$492{ }^{\mathrm{a}}$ The positive control (PC) diet contained $60 \mathrm{mg} / \mathrm{kg}$ of salinomycin

$493 \quad{ }^{\mathrm{b}}$ The negative control (NC) diet did not contain any additives

$494{ }^{\mathrm{c}}$ The divercin supplemented diet contained $200 \mathrm{AU}$ of divercin $/ \mathrm{ml}(0.2 \mathrm{ml} / \mathrm{kg})$

$495{ }^{\mathrm{d}} \mathrm{SEM}$ - standard error of the mean

$496{ }^{\mathrm{e}} P$ - probability

$497{ }^{x, y, z}$ Within rows, mean values without a common superscript differ significantly.

498

499

500

501

502

503

504

505

506

507

508 
Table 4. Counts of coliform and lactic acid bacteria (log cfu./g digesta) and $\mathrm{pH}$ in

Coliforms

Coliforms

Lactic acid bacteria $\mathrm{pH}$

Coliforms

Lactic acid bacteria $\mathrm{pH}$ crop, ileal and caecal digesta

\begin{tabular}{|c|c|c|c|c|c|}
\hline \multirow{3}{*}{ Item } & \multicolumn{3}{|c|}{ Treatment } & \multirow[b]{2}{*}{$\mathrm{SEM}^{\mathrm{d}}$} & \multirow[b]{2}{*}{$P^{\mathrm{e}}$} \\
\hline & $\mathrm{PC}^{\mathrm{a}}$ & $\mathrm{NC}^{\mathrm{b}}$ & DIV $^{\mathrm{c}}$ & & \\
\hline & \multicolumn{3}{|c|}{ Crop } & & \\
\hline Coliforms & 6.98 & 7.08 & 6.55 & 0.110 & 0.112 \\
\hline Lactic acid bacteria & 7.92 & 7.93 & 7.41 & 0.124 & 0.140 \\
\hline \multirow[t]{2}{*}{$\mathrm{pH}$} & $4.33^{x}$ & $3.94^{\mathrm{y}}$ & $4.31^{\mathrm{x}}$ & 0.189 & 0.011 \\
\hline & \multicolumn{3}{|c|}{ Ileum } & & \\
\hline Coliforms & 6.47 & 6.29 & 6.24 & 0.144 & 0.785 \\
\hline Lactic acid bacteria & $7.90^{\mathrm{y}}$ & $7.72^{\mathrm{y}}$ & $7.03^{\mathrm{x}}$ & 0.142 & 0.015 \\
\hline \multirow[t]{2}{*}{$\mathrm{pH}$} & $6.28^{x}$ & $5.14^{\mathrm{y}}$ & $5.55^{\mathrm{x}}$ & 0.376 & 0.001 \\
\hline & \multicolumn{3}{|c|}{ Caecum } & & \\
\hline Coliforms & 7.88 & 7.71 & 7.13 & 0.191 & 0.253 \\
\hline Lactic acid bacteria & $9.24^{\mathrm{x}}$ & $8.53^{\mathrm{y}}$ & $8.00^{\mathrm{y}}$ & 0.180 & 0.006 \\
\hline $\mathrm{pH}$ & $5.49^{y}$ & $5.78^{x}$ & $5.52^{\mathrm{y}}$ & 0.181 & 0.043 \\
\hline
\end{tabular}

$512{ }^{\mathrm{a}}$ The positive control (PC) diet contained $60 \mathrm{mg} / \mathrm{kg}$ of salinomycin

$513 \quad{ }^{\mathrm{b}}$ The negative control (NC) diet did not contain any additives

$514{ }^{\mathrm{c}}$ The divercin supplemented diet contained $200 \mathrm{AU}$ of divercin $/ \mathrm{ml}(0.2 \mathrm{ml} / \mathrm{kg})$

$515{ }^{\mathrm{d}} \mathrm{SEM}$ - standard error of the mean

$516{ }^{\mathrm{e}} P$ - probability

$517 \quad \mathrm{x}, \mathrm{y}, \mathrm{z}$ Within rows, mean values without a common superscript differ significantly. 
Table 5. Concentrations of organic acids ( $\mu \mathrm{mol} / \mathrm{g}$ digesta) in the contents of crop,

Acetic acid

Butyric acid

Lactic acid

Succinic acid

Total organic acids

Acetic acid

Lactic acid

Succinic acid

Total organic acids

Acetic acid

Propionic acid

Isobutyric acid

Butyric acid

Isovaleric acid

Valeric acid

Succinic acid

Total organic acids ileum and caecum of broiler chickens.

ileum and caecum of broiler chickens.

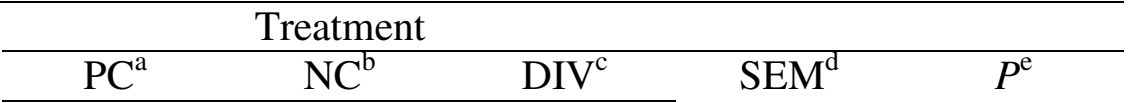

Crop

11

11.3
0.2
55.3

$2.8^{\mathrm{y}}$

$69.7^{\mathrm{y}}$

Ileum

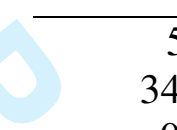

\section{8}

$40.7^{\mathrm{z}}$

Ceacum

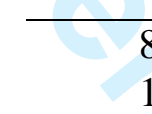

86.5

18.4

0.9

19.8

0.5

3.4

$\mathrm{ND}^{\mathrm{f}}$

129.5 $26.8^{\mathrm{x}}$

0.7

$119.0^{\mathrm{x}}$

$8.7^{\mathrm{x}}$

$155.0^{\mathrm{x}}$

6.1

$114.0^{\mathrm{x}}$

$2.0^{\mathrm{x}}$

$122.0^{x}$

92.0

16.8

1.2

23.1

0.6

2.9

0.7

$52.0^{\mathrm{y}}$

$3.2^{\mathrm{y}}$

$67.3^{\mathrm{y}}$

4.2

$72.4^{\mathrm{y}}$

$0.7^{\mathrm{y}}$

$77.2^{\mathrm{y}}$

4,35

141.0

$11.4^{\mathrm{y}}$
2.23

$<0.001$

0.16

9.59

0.79

12.36

0.49

10.37

0.27

10.69

0.456

$<0.001$

$<0.001$
$<0.001$

$526 \quad{ }^{a}$ The positive control (PC) diet contained $60 \mathrm{mg} / \mathrm{kg}$ of salinomycin

$527{ }^{\mathrm{b}}$ The negative control (NC) diet did not contain any additives

$528{ }^{\mathrm{c}}$ The divercin supplemented diet contained $200 \mathrm{AU}$ of divercin $/ \mathrm{ml}(0.2 \mathrm{~m} / \mathrm{kg})$

$529{ }^{\mathrm{d}}$ SEM - standard error of the mean

$530 \quad{ }^{\mathrm{e}} P$ - probability

$531{ }^{\mathrm{f}} \mathrm{ND}-$ not detected

532

${ }^{\mathrm{x}, \mathrm{y}, \mathrm{z}}$ Within rows, mean values without a common superscript differ significantly.

533

534 